Hanifiya: Jurnal Studi Agama-Agama

ISSN 2089-8835

Volume 2 Nomor 2 Tahun 2019: 89-104

\title{
KISAH PEMBERANTASAN BID'AH DI MALAYSIA: KAJIAN ATAS KITAB RISALAH AL-AZHARI
}

\author{
Wan Zailan Kamaruddin Wan Ali \\ Universiti Malaya, Malaysia \\ wzk_ali@um.edu.my \\ Ahmad Zuhdi Ismail \\ Universiti Malaya, Malaysia \\ f7zuhdi@um.edu.my
}

\begin{abstract}
This article aims to study the idea and thought of Shaikh Muhammad Tahir Jalaluddin alFalaki al-Azhari on the concept of bid'ah [innovation] dan the issues related to it. Bid'ah [innovation] is a problematic issue among muslim society in Malaysia. Generally, it is due to two main streams of thought between Kaum Muda [ultra-ortodox] and Kaum Tua [orthodox] that look at the issues from their own perspectives which are different from one another. In the context of this paper, it focuses to view the idea and thought of Shaikh Muhammad Tahir Jalaluddin himself. Hopefully, it will ease and help the muslim society in Malaysia to interact between them peacefully as allowed in Islam, and not vice-versa.
\end{abstract}

Keywords: innovation; bid'ah; muslim; malaysia.

\section{Abstrak}

Tulisan ini bertujuan mengkaji ide dan pemikiran Syaikh Muhammad Tahir Jalaluddin al-Falaki al-Azhari mengenai konsep bid'ah dan persoalan-persoalan yang berkaitan dengannya. Bid'ah merupakan isu yang problematik dalam masyarakat muslim di Malaysia karena pada umumnya, terdapat dua front pemikiran, yaitu Kaum Muda [ultra-ortodoks] dan Kaum Tua [ortodoks], berdasarkan perspektif yang berbeda. Dalam konteks tulisan ini, ia difokuskan untuk melihat dan memahami ide dan pemikiran Syaikh Muhammad Tahir sendiri. Tulisan ini diharapkan dapat membantu masyarakat muslim di Malaysia sendiri, untuk berinteraksi sesama muslim dalam kerangka perselisihan [al-ikhtilaf] yang dibenarkan Islam dan bukan sebaliknya.

Kata kunci: bid'ah; muslim; Malaysia.

\section{PENDAHULUAN}

Isu perbedaan pemikiran dan pandangan tokoh dan mazhab dalam Islam dalam pelbagai persoalan senantiasa menjadi isu dan bahan perdebatan yang tidak berkesudahan sejak sekian lama. Persoalan bid'ah [innovation] merupakan salah satu isu yang biasa tetapi kini terlepas daripada kebiasaan sehingga menjadi luar biasa.
Isu lain yang turut memainkan peranan dan sangat relevan adalah sikap dan sifat ta'assub [extremism] dalam kalangan masyarakat muslim di manamana saja pun mereka berada sehingga mengundang dan menyemarakkan pertentangan dan perseteruan yang tiada penyelesaiannya, walaupun semuanya merujuk kepada al-Qur'an dan al-Hadith yang dipegang secara 
bersama. Artikel ini coba melihat ide dan pemikiran Syaikh Muhammad Tahir Jalaluddin al-Falaki al-Azhari dalam isu ini dan penyelesaian yang dicadangkannya untuk mengharmonikan perselisihan sesama muslim.

\section{HASIL DAN PEMBAHASAN}

Latar belakang Syaikh Muhammad Tahir Jalaludin al-Falaki (1869-1957):

Nama beliau ialah Muhammad Tahir bin Sheikh Muhammad. Dilahirkan pada tahun 1869 di daerah Kota Tua, Ampek Angkek, Bukit Tinggi, Sumatera barat, Indonesia. Dari segi latar belakang keluarga pula, bapa beliau, Sheikh Muhammad dikenali Sheikh Tjanking, merupakan anak Ahmad Jalaluddin atau Tuanku Sami, kadi golongan Paderi semasa gerakan Paderi (gerakan Wahhabi diasaskan pada 1153/1740 oleh Muhamad bin 'Abd al-Wahhab di Arab Saudi) manakala ibunya, Tuanku Nan Rancak. ${ }^{1}$

Dari segi latarbelakang beliau, dikatakan pada usia 12 tahun belajar di Mekah, tinggal bersama sepupunya Sheikh Ahmad Khatib, ulama bukan Arab pertama dilantik menjadi Imam Besar di Masjid al-Haram, menjalani pendidikan selama 14 tahun di Mekah, kemudian ke Kahirah mempelajari astronomi di madrasah al-Azhar. Di Kaherah, mulai berkenalan dengan tokoh reformis, Sheikh Muhammad 'Abduh (1849-1905), yang menjadi Mufti Besar pada 1899 di Mesir sehingga meninggal dunia 1995. Beliau mempunyai "direct contact" dengan Syed Muhammad Rashid Rida, pengasas majalah al-Manar, mulai diterbitkan pada 1898. Pada tahun 1897, beliau kembali ke Mekah semula dan mengajar astronomi, manakala tahun 1899, beliau kembali ke Sumatra, tetapi tetap memilih Tanah Melayu dan pada 28 September 1899, menetap di Kuala Kangsar, Perak dan berkahwin dengan gadis Melayu, Aishah binti Hj Mustafa bin Datuk Menteri. Salah seorang anak daripada perkahwinan ini ialah Hamdan (Tan Sri Hamdan).

Hasil karya beliau meliputi bahasa Melayu dan Arab. Berikut adalah di antara karya berbahasa Arab seperti Ithaf al-murid fi Ahkam al-Tajwid; Natijah al-Ummi; Tatimmah al-Irsyad al-Hair ilmi al-Fara'id; Tadhkirah Muttabi' al-Sunnah Fi al-Radd 'ala al-Qaili bi Sunnati rak'ataini qabla al-Jumuah.

Karya beliau berbahasa Melayu pula terdiri daripada Perisai orang Beriman Pengsi Mazhab; Pati Kiraan Pada Menentukan Waktu yang Lima; Ini Huraian Yang Membakar "Taman Persuratan"; Risalah Penebas Bida'ahBida'ah di Kepala Batas. Artikel terjemahan pula di antaranya artikel yang paling berkesan bertajuk "Qada' dan Qadar," daripada al-'Urwah alWuthqa merupakan suatu percobaan memujuk orang Melayu mempelajari agama mereka yang sebenar dan beriman dengannya.

Beliau meninggal dunia pada 1957 dengan meninggalkan mesej iaitu konsep Islam menurut pandangan Fundamentalis dan tindakan reformis untuk generasi akan datang demi kebaikan dan kegemilangan mereka.

Pendahuluan kata-kata Syaikh Muhammad Tahir dalam Risalahnya:

"Saudara-saudara sekalian apabila kita insaf dan kita perhatikan keadaan hal yang ada kita padanya masa ini nescaya kita dapati diri kita di tepi tebing yang

\footnotetext{
${ }^{1}$ Abu Bakar Hamzah, "Sheikh Tahir Jalalu'ddin" dlm. Medium, Akademi Islam, Universiti Malaya, Tahun 1, Bil.1, 1409/1988, h.88-95.
} 
tengah runtuh karena kita telah meninggalkan perkara-perkara agama kita, dan kita lemparkan dia ke belakang kita, dan kita tiada berkehendak kepadanya, dan tidak kita perdulikan dia. Kemudian daripada itu, berkekalan kita di lubuk kejahilan dan kawah kebodohan: Jadilah kita tiada tahu membedakan antara yang berguna dan yang membinasakan, dan kita tinggalkan barang yang wajib kita peliharakan daripada perangai dan adat yang dipaksakan dia oleh datuk nenek kita daripada perkara yang berguna dan bersetujuan dengan masa, dan diseru kepada memegangnya oleh agama kita yang suci, dan kita biarkan saja perkara yang wajib kita betulkan daripada perangai dan adat oleh karena ada yang terlebih baik atau karena tiada bersetujuan dengan masa atau karena tiada berbetulan dengan barang yang diseru Allah dan Rasul-Nya. Dan kita bertekun mengerjakan yang bid'ah-bid'ah dan yang munkar-munkar dan kita berbantah-bantah pada perkara yang bersalah-salahan padanya fahaman kita dan tidak kita kembalikan dia kepada yang disuruh Allah, mengapa? Tidakkah yang demikian itu daripada kejahilan kita pada perkara agama kita? Dan kita teperdaya dengan perkataan awam bahwasanya kita alim ulama dan guru mursyid pada agama, na'udhu bi'l-Llah mina'lghurur wa min syarr iblis alghurur." 2

\footnotetext{
${ }^{2}$ Syaikh Muhammad Tahir Jalaluddin, Kitab Risalah Penebas - Bid'ah-Bid'ah di Kepala Batas, h.4-5.
}

Allah SWT telah berfirman di dalam al-Qur'an [yang artinya]:

"Maka jika kamu berbantahbantah pada sesuatu perkara, maka hendaklah kamu kembalikan dia kepada Kitab Allah dan Sunnah Rasulullah, jika ada kamu beriman dengan Allah dan Hari Yang Kemudian, yakni jika ada kamu sebenar-benarnya percaya akan Allah dan Hari Kiamat, yang demikian itu terlebih baik dan sebaik-baik jalan dan penerangan."

Dan firman-Nya [yang artinya]:

“Dan barang apa didatangkan kepada kamu oleh Rasulullah maka hendaklah kamu ambil akan dia dan kerjakan dan barang apa dilarangnya daripadanya maka hendaklah kamu rentikan dan tinggalkan."3

Dan firman-Nya lagi [yang artinya]:

"Maka tidak demi Tuhanmu, demi Tuhanmu tidak percaya mereka akanmu, hingga mereka jadikanmu hakim pada perkara perbantahan yang di antara mereka kemduian tidak jadi kepicikan dan keberatan pada diri mereka menerima hukuman engkau itu dan mengikut mereka dengan sebenarnya tidak mereka membantahi hukuman engkau itu." $^{4}$

Daripada keterangan Syaikh Muhammad Tahir Jalaluddin, dapatlah diringkaskan bahwa masyarakat muslim khususnya Melayu dikatakan berada dalam "lembah kebodohan" karena meninggalkan agama [Islam]. Mereka tidak dapat membedakan yang

\footnotetext{
${ }^{3}$ Al-Qur'an, surah al-Hasyr (59): 7.

${ }^{4}$ Ibid, h.6. [Al-Qur'an, surah al-Nisa' (4):

65]
} 
benar dan berguna, dan meninggalkan perkara yang wajib dengan menjaga perkara yang bersangkut paut dengan adat warisan nenek moyang secara turun menurun.

Penolakan perkara yang wajib adalah disebabkan adat dan kepercayaan lampau yang dianggap lebih baik dan bersesuaian dengan masa meskipun bertentangan dengan kehendak Allah dan Rasul-Nya. Justeru, masyarakat dikatakan lebih suka mengerjakan perkara bid'ah dan munkar, seterusnya berselisih pendapat dan pemahaman tanpa merujuk kepada alQur'an dan al-Sunnah. ${ }^{5}$ Perkara ini terjadi demikian disebabkan kejahilan dan keterpedayaan mereka dengan ucapan alim ulama dan guru mursyid agama.

Persoalan-persoalan berikut merupakan beberapa isu yang dilihat oleh beliau, telah dilakukan oleh masyarakat muslim Melayu di Malaysia khususnya dan di nusantara umumnya tanpa merujuk kepada dua sumber utama dalam Islam, al-Qur'an dan alSunnah [al-Hadith]. Persoalanpersoalan tersebut adalah seperti berikut:

\section{Persoalan Salat Jum'at}

Syaikh Muhammad Tahir mengatakan: "Wahai saudara-saudara ketahuilah bahwasanya sembahyang Jum'at itu difardhukan oleh Allah pada waktu zawal [gelincir] hari Jum'at dua raka'at dengan dua khutbah atas tiaptiap Muslim lelaki 'aqil baligh merdeheka tetap pada sepotong bumi." Keterangan tersebut adalah berdasarkan kepada hadith Nabi [s.a.w]:

"Bermula Jum'at itu hak yang wajib atas tiap-tiap muslim melainkan empat, hamba yang dimiliki, perempuan, kanak-kanak atau yang sakit." (Riwayat Abu Dawud)

"Siapa-siapa yang meninggalkan tiga kali Jum'at hal keadaannya meringan-ringankan nescaya dimeterikan oleh Allah atas hatihatinya." (Riwayat Abu Dawud)

Persoalan yang menimbulkan isu dan perbahasan baik sunnah atau bid'ah adalah mengenai jumlah jamaah yang sah untuk menghadiri solat Jum'at tersebut, baik adakah ia mencakupi jumlah yang ramai ataupun sedikit. Ini karena tidak terdapat ketetapan nass yang jelas tentang jumlah dan jumlah tersebut. Berikut adalah keterangan al-Qur'an:

$\begin{array}{lrr}\text { "Apabila diseru untuk } \\ \text { melaksanakan } & \text { sembahyang }\end{array}$ Jumaat pada hari Jumaat, maka hendaklah kamu bersegera untuk mengingati Allah." ${ }^{6}$

Perkara yang menimbulkan perselisihan dalam kalangan ulama adalah mengenai jumlah dan bilangan yang perlu ada untuk melaksanakan solat pada hari tersebut. Pandangan para ulama pada umumnya terbahagi kepada beberapa kumpulan seperti pada tabel 1.

Dijelaskan bahwa perbedaan pandangan tersebut karena tidak ada ketetapan tertentu dalam menentukannya, cuma yang disyaratkan adalah jumlah kumpulan yang mendiami sesuatu kawasan (qaryah) dan boleh melakukan urusan jual beli (muamalat).

\footnotetext{
${ }^{5}$ Al-Qur’an, surah al-Nisa' (4): 59.
}

${ }^{6}$ Al-Qur'an, surah al-Jumu'ah (62): 9. 
Tabel 1 Pandangan Ulama dalam Salat Jum'at

\begin{tabular}{|c|c|c|}
\hline No. & Tokoh & Pendapat \\
\hline 1. & Ibn Hazm & $\begin{array}{l}\text { Imam dengan } \\
\text { makmum saja }\end{array}$ \\
\hline 2. & $\begin{array}{l}\text { Al-Nakha'i dan } \\
\text { Ahl al-Zahir }\end{array}$ & 3 orang saja \\
\hline 3. & $\begin{array}{l}\text { Abu Yusuf dan } \\
\text { Muhammad }\end{array}$ & 2 orang \\
\hline 4. & $\begin{array}{l}\text { Awza'i, Abu } \\
\text { Nasir, Abu al- } \\
\text { Thawri. } \\
\text { Pendapat Abu } \\
\text { Hanifah menjadi } \\
\text { pilihan al-Muzni } \\
\text { (sahabat al- } \\
\text { Syafi'i) daripada } \\
\text { al-Thawri, al- } \\
\text { Layth dan } \\
\text { kebanyakan } \\
\text { pendapat para } \\
\text { sahabat al- } \\
\text { Syaf'i. }\end{array}$ & $\begin{array}{ll}4 & \text { orang } \\
\text { saja } & \end{array}$ \\
\hline 5. & $\begin{array}{l}\text { Al-Suyuti } \\
\text { berhujah dengan } \\
\text { pendapat al- } \\
\text { Syafi'i }\end{array}$ & orang \\
\hline 6. & $\begin{array}{l}\text { Pendapat } \\
\text { Ikrimah }\end{array}$ & $5 \quad$ orang \\
\hline 7. & $\begin{array}{l}\text { Pendapat } \\
\text { Rabi'ah }\end{array}$ & 9 orang \\
\hline 8. & $\begin{array}{l}\text { Pendapat al- } \\
\text { Mutawali, al- } \\
\text { Mawardi, al- } \\
\text { Zuhri dan } \\
\text { Muhammad al- } \\
\text { Hasan }\end{array}$ & 12 orang \\
\hline 9. & Pendapat Ishak & 13 orang \\
\hline 10. & Pendapat Malik & 20 orang \\
\hline 11. & $\begin{array}{l}\text { Mazhab Syafi'i } \\
\text { daripada Umar } \\
\text { Abd al-Aziz }\end{array}$ & 40 orang \\
\hline 12. & Ahmad & 50 orang \\
\hline 13. & Al-Mawardi & 80 orang \\
\hline 14. & Mazhab Maliki & $\begin{array}{l}\text { Jumlah yang } \\
\text { ramai tidak } \\
\text { ditentukan } \\
\text { jumlah } \\
\text { jumlahnya-. }\end{array}$ \\
\hline
\end{tabular}

Analisis dan komentar daripada pelbagai pendapat tersebut menurut Syaikh Muhammad Tahir:

Menurut al-Suyuti dan para ulama lain, tidak terdapat hadith dan ijma' para Imam [mazhab] tentang jumlah jumlah tersebut. Beliau berhujah dengan menggunakan pendapat alSayyid 'Abd al-Rahman, Mufti al-Diyar al-Hadramiyyah yang mengatakan bahwa sekiranya dalam suatu kampung tersebut terdapat jumlah yang kurang untuk melaksanakan solat Jum'at karena kesukaran untuk menunaikannya maka solat Jum'at wajib dilakukan, dan persoalan kekurangan dalam jumlah jumlahnya adalah diharuskan. ${ }^{7}$

Riwayat al-Zuhri daripada Abu Salamah bersumberkan Abu Hurairah tentang jumlah lelaki untuk solat Jum'at pula, dikatakan Abu Hurairah berkata apabila jumlah sahabat mencapai jumlah 50 orang maka Rasulullah melaksanakan solat Jum'at.

Riwayat daripada Ahmad Ibn Hanbal pula mengatakan solat Jum'at sah dilakukan dengan tiga orang saja, karena tiga orang mencapai tahap [atau maksud] jamak sama seperti jumlah 40 orang. Pendapat ini diambil daripada al-Awza'i dan Abu Thaur. Abu Hanifah [al-Nu'man] mengatakan salat Jum'at sah dengan 4 orang saja sama dengan jumlah jumlah 40 orang.

Menurut Rabi'ah pula dikatakan ia sah dengan 12 orang lelaki, berdasarkan hadith Rasulullah [s.a.w] yang menyuruh Mus'ab bin 'Umair di Madinah melaksanakan solat Jum'at dengan dihadiri 12 orang lelaki saja.

Muslim mengambil riwayat daripada Jabir menyebutkan, pada hari Jum'at kami bersama-sama Rasulullah [s.a.w] dengan 12 orang melaksanakan

${ }^{7}$ Ibn Qudamah, Kitab al-Mughni, Juz.1, h.172-173. 
solat tersebut karena pada masa yang sama, sekumpulan peniaga datang berniaga sehingga menyebabkan ramai daripada kumpulan tersebut lari meninggalkan Rasulullah [s.a.w], lalu ayat al-Qur' an berikut diturunkan:

"Apabila mereka melihat

kumpulan peniaga datang lalu mereka meninggalkan solat tersebut." $^{\prime 8}$

Riwayat Ka'b bin Malik menyebutkan, pada tahap pertama ketika melaksanakan solat Jum'at di perkampungan Bani Bayadah, Naqi' alHadamat, jumlah jamaah solat adalah seramai 40 orang. (Riwayat Abu Dawud dan al-Athram).

Dalam kitab al-Ahkam al-Qur'an ${ }^{9}$ oleh Hujjatu'l-Islam al-Razi [m.370] beliau menyenaraikan pelbagai pendapat, di antaranya:

Tabel 2 Perbedaan Pendapat dalam jumlah Makmum Salat Jum'at

\begin{tabular}{lll}
\hline \multicolumn{1}{c}{ Nama } & Pendapat & $\begin{array}{c}\text { Jumlah } \\
\text { keseluruhan }\end{array}$ \\
\hline $\begin{array}{l}\text { Abu } \\
\text { Hanifah, }\end{array}$ & $\begin{array}{l}\text { Imam } \\
\text { dengan } 3\end{array}$ & 4 orang \\
$\begin{array}{l}\text { Zuqir, } \\
\text { Muhammad, } \\
\text { al-Layth }\end{array}$ & $\begin{array}{l}\text { makm } \\
\text { Abu Yusuf }\end{array}$ & \\
dan al- & Imam & 3 orang \\
Thawri & orang & \\
& makmun & \\
\hline $\begin{array}{l}\text { Al-Hasan } \\
\text { bin Salih dan }\end{array}$ & Imam dan & 2 orang \\
Malik & makmun & \\
\hline Al-Syafi'i & 40 orang & 40 orang \\
& lelaki & \\
\hline
\end{tabular}
Jabir berdasarkan riwayat daripada Abu Bakr menyebutkan, ketika Nabi [s.a.w] sedang berkhutbah, tiba-tiba sekumpulan peniaga datang untuk berniaga hingga menyebabkan

\footnotetext{
8 Al-Qur'an, surah Juma'ah (62): 11.

${ }^{9}$ Al-Razi [m.370], Kitab al-Ahkam al-Qur'an, h.550.
}

jumlah [jamaah] yang tinggal hanyalah 12 orang saja karena yang lain lari meninggalkan Rasulullah [s.a.w] sehinggalah baginda [s.a.w] selesai mendirikan solat Jum'at.

Perintah Nabi [s.a.w] kepada Mus'ab bin 'Umair untuk melakukan solat Jum'at di Madinah dengan jumlah 12 orang saja. Dengan jumlah tersebut maka jumlah 40 orang dianggap terbatal. Jumlah 3 adalah sesuai dengan jamak (kumpulan) dan sama seperti 40 orang. Jumlah yang kurang daripada 3 adalah bertentangan dengan maksud jamak.

Al-Hafiz Jalal al-Din al-Suyuti ${ }^{10}$ mengeluarkan pendapat: Sa'id bin Mansur, Ibn Sa'd, Ibn Abi Syaibah, Ahmad bin Hanbal, 'Abd bin Hamid, alBukhari, Muslim, al-Tirmidhi, Ibn Jarir, Ibn al-Mundhir, Ibn Mardawayh dan alBayhaqi di dalam sunannya daripada beberapa cara mengikuti Jabir bin 'Abdullah: Ketika baginda [s.a.w] berkhutbah pada hari Jum'at, sekumpulan peniaga yang datang menyebabkan beberapa orang sahabatnya lari meninggalkan Rasulullah [s.a.w], dan yang tinggal hanyalah 12 orang saja lalu ayat tersebut diwahyukan.

Solat Jum'at merupakan fardu 'ain. Justeru, sekiranya dalam sebuah kampung tersebut terdapat 3 orang lelaki yang akil baligh dan merdeka maka wajiblah mereka diwajibkan mendirikan solat Jum'at karena jumlah 3 adalah mewakili jamak yang sebenarnya. Keterangan ini berdasarkan kepada sebuah hadith baginda [s.a.w]:

"Sekiranya tidak ada orang melainkan 3 orang saja dalam satu kampong yang didiami oleh

\footnotetext{
${ }^{10}$ Al-Suyuti, Jalal al-Din, al-Durr al-Manthur, h. 220 .
} 
penduduk badwi, mereka tidak melakukan solat (Jum'at) secara berjamaah maka mereka akan dikuasai syaitan. (Riwayat Ahmad, Abu Dawud, al-Nasa'i, Ibn Hibban, al-Hakim daripada hadith Abi al-Darda')

Golongan yang mengatakan hadith Jabir adalah daif [lemah] tidak dapat diterima karena tidak ada bukti yang kuat dapat mendukungnya. Tambahan pula, golongan yang meninggalkan baginda [s.a.w] ketika sedang berkhutbah juga tidak dapat dibuktikan bahwa mereka semua kembali semula untuk meneruskan solat bersama-sama dengan Rasulullah [s.a.w]. Justeru, jumlah yang tinggal bersama-samanya adalah seramai 12 orang. Lagipun Nabi [s.a.w] tidak pernah meninggalkan solat Jum'at semenjak baginda berada di Madinah. Golongan yang berpendapat dengan jumlah 12 orang adalah qaul yang muktamad dalam mazhab Syafi'i karena hadith Jabir telah ditashihkan oleh kutub al-Sihah. ${ }^{11}$

Secara ringkas, golongan yang berpegang dengan jumlah jumlah 40 orang merupakan ahl bid'ah yang mengerjakan segala bid'ah dalam masjid pada hari Jum'at dan mereka tidak menghadap 'ain kiblat dalam solat hanya menuju kiri dan kanan kiblat. Apa yang peliknya, mereka mendakwa diri mereka adalah bermazhab Syafi'i.

\section{Persoalan Solat Jum'at diiringi Solat Duhur}

Solat Duhur selepas solat Jum' at di Pulau Pinang dan Singapura adalah tidak wajib dan tidak sunat bahkan menjadi bid'ah dan tidak dibenarkan oleh Allah [s.w.t] karena berbilang-

${ }^{11}$ Lihat: al-Hafiz al-Suyuti.

${ }^{12}$ Al-Qur'an, surah al-Baqarah (2): 144, 149, 150. bilang Jumaatnya. Ia menjadi harus karena hajat. Jumaatnya sah sekiranya betul dan menuju 'ain qiblah [tepat ke arah Kiblat].

\section{Persoalan Mengenai Kiblat:}

Mengadap kiblat merupakan syarat sah solat bagi mazhab Syafi'i. Ketetapan tersebut berdasarkan kepada firman Allah:

"Maka hendaklah kamu menghadapkan wajah kamu kepada pertengahan masjid alHaram karena Ka'bah berada di tengah-tengah masjidil-haram dan di mana kamu berada maka hendaklah kamu hadapkan muka kamu kepada tengahnya." ${ }^{12}$

Merujuk kepada perkataan syatr al-syai' dari sudut bahasa Arab bermaksud tengah. Keterangan ini adalah berdasarkan sabda Rasulullah [s.a.w]. Beliau telah menulis surat kepada Mus'ab tentang istilah tersebut iaitu apabila matahari condong daripada syatrnya iaitu pertengahan pada hari Jum'at, maka hendaklah berbuat taat kepada Allah dengan dua raka' at sehingga sempurna.

Al-Syafi'i ${ }^{13}$ dalam al-Umm mengatakan sekiranya seseorang berada di Makkah atau di luar Makkah dengan tidak nampak Ka'bah maka seseorang itu tidak boleh meninggalkan solat fardhu melainkan berusaha (ijtihad) untuk mencari arah kiblat dengan segala bentuk hujah baik daripada bintang, matahari, bulan, gunung, tempat yang ditiup angin dan segala bentuk yang memberi petunjuk ke arah Ka'bah.

Ibn Hajr al-Haythami ${ }^{14}$ dalam Fath al-Jawwad mengatakan sekiranya tidak terdapat orang yang pakar dalam

\footnotetext{
${ }^{13}$ Muhammad bin Idris al-Syafi'i, al-Umm, I, h.81.

${ }^{14}$ Ibn Hajr al-Haythami, Fath al-Jawwad, h.75.
} 
menentukan Ka'bah maka seseorang pemimpin wajib berijtihad untuk menentukan arah kiblat dengan dalilnya. Dalam keadaan ini, mereka tidak boleh bertaklid dan tidak boleh menerima secara zann (sangkaan) tanpa bukti yang sahih. Sekiranya dilakukan juga maka mereka wajib mengulangi solat tersebut walaupun arah Ka'bahnya betul.

Di sini terdapat suatu perkara yang pelik dan menghairankan dalam kalangan guru yang mengaku bermazhab Syafi'i iaitu mestilah menghadap Ka'bah ketika solat tetapi membenarkan pula menghadap ke arahnya (jihah) saja sebagaimana yang dinyatakan oleh Nuri iaitu mengadap kiri dan kanan bukannya ain (tengah) Ka'bah.

Dalam situasi ini, Nuri sendiri bertegas mengatakan bahwa Allah SWT menjadikan Ka'bah sebagai kiblat bagi solat. Allah menyuruh manusia mengadap dan menuju ke arahnya.

\section{Persoalan Mengenai Perintah Allah - boleh diubah atau tidak}

Menurut Abu al-Husayn, sesiapa yang berpegang kepada pendapat dan hukum al-Nuri seperti memadai dalam setiap solat menghadap kiri atau kanan Ka'bah, mereka dikatakan telah berpegang kepada agama Allah, manakala sekiranya mereka mengingkari pendapat tersebut, maka seseorang itu dikatakan telah sesat mengikut hawa [nafsu], semoga Allah [s.w.t] memusnahkan golongan yang sesat sehingga diberi petunjuk.

Itulah sebabnya saya (Syaikh Tahir) berkata: "kita tidak tahu untuk membedakan bubur dengan lumpur dan tepung dengan kapur."

\section{Pengertian Sunnah dan Bid'ah}

Dalam Kitab Irsyad al-Fuhul mendefinisikan sunnah ${ }^{15}$ dari segi bahasa bermaksud jalan terbentang yang boleh dilalui orang. Dari segi istilah, ia bermaksud perkara yang berhubung dengan perkataan, perbuatan dan ketetapan Nabi [s.a.w] ( meliputi diam dan tidak menegur perbuatan seseorang di hadapan Nabi [s.a.w] atau sampai khabar kepadanya). ${ }^{16}$

Justeru, apabila seseorang itu berkata dengan sunnah Nabi [s.a.w] bermaksud Nabi [s.a.w] melaksanakannya, sebaliknya sekiranya Nabi [s.a.w] tidak melakukannya, tidak mengatakannya dan tidak menetapkannya maka seseorang itu telah membohongi dan berdusta kepada Rasulullah [s.a.w]. Perkara sebegini adalah bertentangan dan baginda [s.a.w] telah berjanji bahwa sesiapa yang membohonginya maka tersedialah tempatnya dalam neraka di akhirat kelak.

Pengertian $b i d^{\prime} a h^{17}$ pula merujuk kepada sesuatu perbuatan yang tidak wujud pada masa Rasulullah [s.a.w]. Bid'ah pula terbahagi kepada dua bahagian:

a) Bid'ah Syar'iyyah

b) Bid'ah Lughawiyyah.

Bid'ah Syar'iyyah merupakan perkara yang berhubungan erat dengan aspek akidah dan ibadat, dengan sebarang tambahan dalam perkara akan mengakibatkan kesesatan (dalalah). Setiap bid'ah adalah dalalah, dan setiap dalalah dalam neraka. Baginda [s.a.w] dikatakan bersabda:

"Hendaklah kamu menjauhi segala bentuk bid'ah karena setiap bid'ah adalah sesat, setiap

\footnotetext{
${ }^{17}$ Ibn Hajar, al-Fatawa al-Hadithihiyyah, h.112.
}

${ }^{15}$ Kitab Irsyad al-Fuhul, h. 31

${ }^{16}$ Kitab Risalah Penebas, h.19. 
kesesatan membawa [seseorang] kepada api neraka." (Riwayat Ibn Asakir, lihat: Kanz al-Ummal, I, hlm. 56)

Bid'ah Lughawi pula merangkumi 5 perkara yang lazimnya dibincangkan dalam konteks hukum bahasa.

\section{Persoalan Hari Jumaat dan perkara berkaitan dengannya}

Perkara pertama yang berlaku pada hari Jum'at adalah:

a) Adakah Imam naik ke atas mimbar sebelum azan yang pertama atau selepasnya?

b) Apakah yang dikatakan sunnah Nabi [s.a.w] atau bid'ah?

Syaikh Tahir mengemukakan sebuah hadith dalam Sahih al-Bukhari, hlm. 8. Dalam hadith tersebut, al-Sa'ib bin Yazid mengatakan bahwa seruan (azan) bermula apabila Imam / Khatib duduk di atas mimbar. Keadaan ini bermula pada masa Rasulullah [s.a.w], Abu Bakr, 'Umar dan 'Uthman.

Al-Razi ${ }^{18}$ mengemukakan pendapat al-Zuhri daripada al-Sa'ib bin Yazid yang menceritakan keadaan yang berlaku pada hari Jum'at. Menurutnya, orang yang melaungkan seruan (azan) pada hari Jum'at memulakan tugasnya apabila Rasulullah [s.a.w] duduk di atas mimbar. Khalifah Abu Bakr dan 'Umar melakukan perkara yang sama seperti baginda [s.a.w].

Waki', guru kepada al-Syafi'i menceritakan peristiwa tersebut kepada Hisyam bin al-Ghar. Berdasarkan jawapan Nafi' daripada 'Abdullah bin 'Umar memperlihatkan bahwa azan yang pertama adalah bid'ah.

Terdapat sekumpulan ulama Salaf mengubahkan cara yang dilaksanakan oleh baginda [s.a.w] dengan memulakan seruan azan pertama sebelum Imam / Khatib berada di atas mimbar. Inilah bid'ah pertama yang berlaku pada hari Jum'at, dan setiap bid'ah adalah sesat.

Selanjutnya, persoalan memimpin khatib menaiki mimbar tidak berlaku pada masa Nabi [s.a.w], Khulafa alRasyidin dan al-Tabi'in. Justeru, perbuatan tersebut adalah bid'ah.

\section{Persoalan Solat dua rakaat Qabliyyah Jum'at}

Solat sunat dua raka'at sebelum solat Jum'at yang dilakukan oleh orang ramai di dalam masjid selepas azan adalah bid'ah. Perbuatan tersebut tidak pernah dilakukan oleh Nabi [s.a.w], para sahabat dan al-Tabi'in. Meskipun terdapat hadith yang membenarkan solat sunat dilakukan di antara dua azan (azan dan iqamah), tetapi tidak menetapkan solat sunat qabliyyah Jum'at. Tradisi Nabi [s.a.w] iaitu memulakan azan untuk solat Jum'at ketika beliau berada di atas mimbar. Tradisi ini diikuti oleh $\mathrm{Abu}$ Bakr dan 'Umar. Al-Bukhari mengeluarkan hadith:

"Apabila Khalifah 'Uthman
memerintah, menambahkan satu azan lagi iaitu sebelum Imam / Khatib berada di atas mimbar dengan alasan masyarakat Islam telah bertambah."

Jika dibandingkan dengan keduadua peristiwa tersebut, jelaslah hadith yang menjadi dalil untuk melakukan solat sunat Qabliyyah Jum'at adalah terbatal dan tidak boleh dijadikan hujjah. Para ulama telah bersependapat tentang haram melakukan solat sunat ketika Imam berada di atas mimbar.

${ }^{18}$ Al-Razi, Ahkam al-Qur'an, hlm. 546. 
Muhammad Idris al-Syafi'i membuktikan bahwa solat adalah haram apabila Imam telah menaiki mimbar dengan meriwayatkan hadith mengikuti dua sanad yang disahkan oleh Tha'labah bin Malik (r.a), apabila Imam telah duduk di atas mimbar (masuk waktu Jum'at) maka terputuslah atau tidak boleh melaksanakan solat sunat Jum'at. Beliau berhujah berdasarkan perbuatan yang dilakukan oleh Rasulullah [s.a.w]:

Setelah gelincir matahari pada hari jumaat, beliau masuk ke dalam masjid lalu menaiki mimbar dan terus memberi salam kepada sidang hadirin, kemudian duduk. Bilal mengambil tugas untuk melakukan azan. Nabi selanjutnya menyampaikan khutbah tanpa bersolat dan tidak meyuruh orang ramai melakukan solat melainkan solat tahyat al-Masjid sekiranya terdapat orang yang memasuki masjid. Apabila selesai khutbah, Bilal mengiqamat dan diteruskan dengan pengucapan takbiratul-Ihram untuk melakukan solat jumaat sehinggalah selesai.

Dalil seterusnya adalah: ${ }^{19} \mathrm{Umm}$ alMu'minin 'A'isyah mengatakan bahwa setelah Nabi (s.a.w) selesai mengucapkan salam, baginda (s.a.w) duduk sekadar mengucapkan:

"Allahumma anta al-salam, wa minka al-salam, tabarak-ta ya dha'l-Jalal wa'l-Ikram". ${ }^{20}$

Ibn Umar berkata: setelah selesai solat Jum'at, Nabi [s.a.w]. melakukan solat sunat dua rakaat di rumahnya. ${ }^{21}$ Ibn Abi al-Akwa' mengatakan bahwa ketika bersolat Jum'at bersama-sama Nabi [s.a.w]. Tidak ada solat yang mengiringi solat Jum'at. Ibn Hajr al-
'Asqalani al-Syafi'i dalam al-Fath ${ }^{22}$ menerangkan bahwa tidak ada dalil yang jelas tentang solat sunat qabliyyah.

Abu Syamah al-Syafi'i dalam kitabnya al-Ba'ith 'ala Ingkar al-Bida'i wa al-Hawadith ${ }^{23}$ menerangkan bahwa solat sunat qabliyyah Jum'at tidak ada pada masa Rasulullah [s.a.w] dan tidak boleh diqiyaskan untuk mensyariatkan solat tersebut.

Al-'Allamah Majd al-Din alSyirazi al-Syafi'i dalam Safar al-Sa'adah ${ }^{24}$ menerangkan bahwa apabila selesai bilal melaungkan azan, Nabi [s.a.w] memulakan pembacaan khutbah tanpa ada seorang pun yang bangkit untuk solat sunat.

Sebahagian ulama yang membenarkan solat sunat Jum'at dengan mengqiyaskannya kepada solat sunat Duhur. Mereka telah berusaha secara bersungguh-sungguh untuk mengarang beberapa buah kitab berhubung dengan perkara-perkara sunnah tanpa dalil yang kuat untuk dijadikan bukti khususnya solat sunat qabliyyah Jum'at.

\section{Buktinya}

Al-Hafiz al-Zura'i dalam kitabnya, hlm. 118, menyatakan bahwa para ulama menetapkan sunat qabliyyah Jum'at dengan mengqiyaskannya kepada solat sunat duhur. (Qiyas sebegini adalah tidak boleh dijadikan bukti malah terbatal karena apa yang difahami tentang sunnah Nabi [s.a.w] adalah perkara yang diucapkan atau dilakukan oleh baginda [s.a.w] dan sunnah Khulafa' al-Rasyidin). Apabila tidak ada perkara yang dilakukan oleh Nabi [s.a.w], maka apakah boleh

\footnotetext{
${ }^{19}$ Muslim, Sahih, V, hlm. 90.

${ }^{20}$ Muslim, Sahih, VI, hlm. 167.

${ }^{21}$ Muslim, Sahih, VI, hlm. 148.

${ }^{22}$ Ibn Hajr al-'Asqalani al-Syafi'i, al-

Fath, II, hlm. 279.
}

\footnotetext{
${ }^{23}$ Abu Syamah al-Syafi'i, al-Ba'ith 'ala Ingkar al-Bida' $i$ wa al-Hawadith, hlm. 70.

${ }^{24}$ Majd al-Din al-Syirazi al-Syafi' $i$, Safar al-Sa'adah, hlm. 46.
} 
dijadikan sebagai ketetapan dalam syariat. Justeru, meninggalkan perkara tersebut adalah lebih baik ataupun mengerjakan sunnah Nabi [s.a.w]?

Syaikh al-Tahir menyebutkan kitab Ta'yid Tadhkirah Muttabi'i alSunnah fi al-Radd 'ala al-Qa'il biSunniyatai Rak'atayn Qabla al-Jum'ah yang diperakukan oleh 12 orang ulama Makkah dan Mesir. (Diterjemahkan dalam Bahasa Melayu, terbitan Maktabah Yahya Arif atau Maktabah alZayniyyah, Taiping).

\section{Persoalan Lafaz Usalli}

Melafazkan niat usalli sebelum takbiratu'l-ihram tidak disyariatkan karena tidak terdapat hadith yang sahih atau da'if dan tidak pula terdapat perakuan daripada para Imam yang empat. (Hanafi, Malik, Syafi'i dan Hanbali)

Para ulama yang membenarkan perkataan tersebut di antara mereka ialah al-Ghazali dalam Syarh Ihya', III, h.34 mengeluarkan pendapat al-Rafi'i dan para sahabatnya (sahib al-afsah) yang mengatakan bahwa melafazkan niat dengan lidah adalah wajib, dengan alasan al-Syafi'i mengatakan pada kebiasaannya, orang yang mengerjakan ibadat haji sewaktu ihram, mereka melafazkan niat dengan ucapan lidah bukannya di hati.

Jumhur ulama dalam kalangan alSyafi'i [al-Syafi'iyyah] mengatakan bahwa beliau sebenarnya bukan mengatakan lafaz niat tersebut tetapi mengiktibarkan lafaz tersebut pada takbir, karena solat adalah sah dengan lafaz takbir dan ia berbeda dengan ibadat haji. Pada h. 35, Ibn al-Hammam menyatakan bahwa tidak ada bukti yang sahih atau da'if tentang ucapan Nabi [s.a.w] ketika memulakan solat iaitu "aku solat atau ....". Perkara yang sama dilakukan oleh para sahabat dan al-Tabi'in. Justeru, pengucapan niat adalah bid'ah.

Al-Nawawi dalam al-Majmu 25 mengatakan bahwa berniat dengan hati dan melafazkan dengan lidah tidak termasuk jumlah jumlah solat. Contoh niat adalah: "Saja aku bersolat... (di dalam hati)".

Al-Hafiz al-Zura'i dalam kitabnya, I, h.51, mengatakan bahwa ketika Nabi [s.a.w] memulakan solat, baginda [s.a.w] hanya menyebutkan lafaz Allah Akbar saja tanpa ada perkataan lain yang mengiringinya seperti niat ("Aku bersalat karena Allah, menghadap kiblat, empat raka'at, sebagai Imam, ma'mum, tunai, Qada', fardhu - adalah bid'ah). Tidak terdapat bukti yang jelas baik sahih, da'if, musnad atau mursal dilakukan oleh Nabi [s.a.w], para sahabat, tabi' in dan Imam yang empat. Golongan mutakhir [al-muta'akhkhirin] yang tidak memahami perkataan alSyafi'i saja seperti perkataan dhikr adalah lafaz Allah Akbar.

Suatu perkara yang pelik dilakukan oleh al-Syafi'i adalah mensunatkan perkara yang tidak pernah diperbuat oleh Nabi [s.a.w] di dalam solatnya. Sekiranya ada bukti yang kukuh maka seseorang mesti melakukannya dengan tidak boleh membantah atau mengingkarinya. Justeru, perbuatan melafazkan niat usalli sewaktu hendak bersolat adalah bid'ah.

Lafaz "Sayyidina", al-Syafi'i dalam kitab al-Umm, hlm. 10, daripada Ibrahim bin Muhammad, Safwan bin Salim daripada Abi Salmah bin 'Abd alRahman daripada Abu Hurairah tentang bersalawat kepada Nabi [s.a.w] dalam solat. Baginda [s.a.w] berkata

${ }^{25}$ Al-Nawawi, al-Majmu', h. 276. 
salawat dan salam kepadanya tanpa menyebut lafaz "sayyidina".

Al-Syafi'i mengeluarkan hadith riwayat Ibrahim bin Muhammad, Sa'id bin $\mathrm{Ka}^{\prime} \mathrm{b}$ bin Ujrah daripada 'Abd alRahman bin Abi Laila tentang pengucapan salawat kepada Nabi [s.a.w] dalam solat tanpa menyebutkan lafaz "sayyidina".

Oleh yang demikian, mengikut perintah lebih utama daripada melakukan adab iaitu menjaga dan menyebutkan penghormatan kepada Nabi [s.a.w] dengan menambahkan lafaz "sayyidina".

\section{Persoalan Berdiri Dalam Marhaban}

Tidak terdapat bukti sahih yang boleh dijadikan dalil mengenai persoalan "berdiri" ketika membacakan kisah Mawlid al-Nabi untuk mengalu-alukan kedatangan baginda [s.a.w] ke dunia.

Pada zaman sahabat sehingga kurun ke-3/9, tidak ada orang yang berhimpun untuk membaca kisah hidup baginda [s.a.w] apatah lagi berdiri untuk menyambut kelahirannya. Persoalan "mawlid" dan "berdiri" merupakan perkara yang baharu dan diada-adakan (bid'ah) yang dilakukan oleh raja 'Ajam (bukan Arab) dan ulama mutakhir [muta'akhkhirin].

Rasulullah [s.a.w] bersabda:

"Janganlah kamu berdiri untuk memperbesar-besarkan aku tetapi hendaklah kamu berdiri untuk memperbesar-besarkan Allah [s.w.t] [dalam solat]." ${ }^{26}$ (Riwayat Ahmad Ibn Hanbal)

Ibn Hajr al-Haythami menyebutkan perlakuan dan kelakuan orang ramai sewaktu membaca kisah
Mawlid al-Nabi merupakan bid'ah tanpa ada sebarang bukti yang sahih. ${ }^{27}$

\section{Persoalan Talqin Mayat}

Membaca talqin ke atas mayat adalah bid'ah karena perbuatan tersebut tidak pernah dilakukan oleh Nabi [s.a.w]. Terdapat hadith yang diriwayatkan oleh Abu Dawud yang disahkan oleh al-Hakim bersumber daripada 'Uthman bin al-'Affan yang mengatakan bahwa ketika selesai mengebumikan mayat seseorang, baginda [s.a.w] bangkit berdiri sambil berkata: "pohonkanlah keampunan kepada mayat saudaramu dan mintalah kepada Allah supaya mengurniakan ketetapan dalam menjawab persoalan Munkar dan Nakir."

Ahmad meriwayatkan hadith daripada Abu Sa'id al-Khudri bahwa manusia tidak dapat menghalang kehadiran malaikat penjaga kubur yang mempunyai rupa yang amat dahsyat, hodoh sehingga kelu lidah seseorang apabila berhadapan dengannya. Baginda [s.a.w] dengan tegasnya mengatakan bahwa Allah [s.w.t] telah menetapkan mereka yang beriman kepada-Nya dengan kata-kata La ilaha illa Allah di dunia, maka mereka memperoleh kebahagiaan di alam barzakh. Sebaliknya, mereka yang mendakwa beriman tetapi melanggar hukuman Allah [s.w.t] di dunia, mereka tidak akan diberi petunjuk untuk menjawab pelbagai persoalan di alam barzakh.

Ringkasnya, sabda Rasulullah [s.a.w] tersebut membuktikan bahwa pekerjaan Munkar dan Nakir mesti berlaku ke atas semua mayat, baik anak yang mati dalam kandungan ataupun mayat yang tidak berkubur seperti

\footnotetext{
${ }^{26}$ Riwayat Ahmad Ibn Hanbal, lihat: Kanz al-Ummal, V, hlm. 36.
}

${ }^{27}$ Ibn Hajr al-Haythami, al-Fatawa al-
Hadithiyyah, h. 60. 
terbakar, karam di lautan, dimakan binatang buas dan sebagainya.

\section{Tashih}

Dikatakan: "Wahai saudaraku, solat Jum'at adalah diwajibkan ke atas muslim yang baligh, bermula ketika waktu duhur (zawal) pada hari Jum'at. Jumlah solat adalah dua raka'at, dilaksanakan secara berjamaah. (AlQur'an: Idha nudiya li's-solah...) Hendaklah bersegera mengingati Allah dengan meninggalkan segala bentuk jenis perniagaan. Golongan yang tidak layak menunaikan solat Jum'at terdiri daripada empat iaitu, hamba, wanita, kanak-kanak dan orang sakit. Meninggalkan 3 kali solat Jum'at atau meringan-ringankannya Allah akan mematikan hatinya. Jumlah jama'ah untuk menyempurnakan solat Jum'at tidak ditentukan oleh Rasulullah [s.a.w] baik 3, 4, 12, 40 dan sebagainya menjadi isu perdebatan dalam kalangan ulama."

\section{Analisis}

Analisis dari segi rujukan yang digunakan oleh Syaikh Muhammad Tahir Jalaluddin memperlihatkan bahwa al-Qur'an dan al-Sunnah merupakan dua buah sumber yang wajib dirujuk dalam Islam, dan juga dalam sebarang penjelasan mengenai persoalan-persoalan yang dibahaskan. Dalam konteks al-Qur'an, tafsiran mengenai ayat-ayat terbabit biasanya berlandaskan keterangan yang diterima oleh kedua-dua pihak, kaum Tua [Asy'ariyyah] dan kaum Muda [alSalafiyyah].

Dalam konteks al-Sunnah pula, syarah kepada al-hadith atau al-Sunnah dikemukakan dengan jelas dari segi rujukannya. Beliau mengunapakai alSahihain [al-Bukhari dan Muslim], di samping Kutub al-Sittah [enam buah kitab hadith mu'tabar]. Ini karena kedua-dua aliran pemikiran, ASWJ [Konservatif] maupun Al-Salafiyyah [Ultra-Konservatif] menjadikan kitabkitab tersebut sebagai rujukan primer selepas al-Qur'an. Ini memudahkan proses penghujahan dan pendalilan yang dilakukan. Seterusnya, pembuktian mengikuti logika kekuatan untuk memperkukuhkan hujah dan alasan boleh dilakukan dengan cara yang saksama.

Dalam usaha untuk mendukung keterangan al-Qur'an dan al-Sunnah, Syaikh Muhammad Tahir juga memperkuatkan hujahnya dengan mengemukakan sokongan daripada para ulama' dalam aliran mazhab yang diterima oleh ASWJ khususnya alAsy'ariyyah dan al-Syafi'iyyah yang turut membahaskannya dengan hujahhujah yang selari dengan hujah beliau. Dengan cara ini, beliau bukan saja membuktikan kebenaran hujahnya, bahkan ia bersependapat dengan pandangan dan pendapat tokoh ulama bermazhab Sunni juga.

Seandainya beliau tidak bersependapat dengan pandangan tokoh dan mazhab, beliau akan mengkritik pendapat mereka secara tegas dan memperlihatkan kelemahan dan kekurangannya. Ternyata dalam setiap hujah dan pandangannya menunjukkan beliau benar-benar memahami kedudukan sesuatu persoalan sebelum membuat keputusan, baik disenangi atau tidak. Baginya, ia bukan isu suka atau tidak, tetapi isu kebenaran melawan kebatilan. Ini karena Islam milik Allah dan bukan milik manusia, dan mana-mana manusia muslim mu'min perlu dan bahkan wajib mengikut perintah Allah mengikuti contoh dan teladan yang ditunjukkan oleh Rasulullah (s.a.w). 
Kritikan dan bidasan yang agak keras dihadapkan kepada para alim, ulama, guru mursyid Melayu yang dilihat banyak melakukan penyelewengan data dan fakta dalam pendapat dan pandangan mereka sehingga masyarakat muslim awam disisihkan daripada realitas Islam itu sendiri, dan secara sedikit demi sedikit dibawa menjauh daripada sumbernya yang sebenar.

Daripada komentar yang dikemukakan ia seolah-olah memperlihatkan pimpinan agama dan yang dipimpin dalam agama telah menyimpang daripada Islam yang sebenar. Mereka tidak lagi mengikuti Islam yang dikehendaki Allah dan Rasul-Nya, sebaliknya mengikuti Islam mengikut acuan mazhab yang diperlihatkan sebagai tidak mengikut Islam yang benar. Implikasinya, ia menggambarkan golongan yang berkenaan mengikuti Islam jadi-jadian dan lebih tepat, bukan Islam. Justeru, mereka dilihat dalam kesesatan, dan akibat daripada kesesatan ini menyebabkan mereka menanggung risiko untuk mendiami neraka sebagai tempat pembalasannya.

\section{Al-Sunnah dan al-Bid'ah}

Dalam teks ini, beliau juga turut membincangkan persoalan al-sunnah dan al-bid'ah dengan menunjukkan perbedaannya untuk dikenalpasti. Kedua-dua persoalan ini merupakan persoalan utama dalam teks ini, manakala topik yang dibahaskan adalah contoh-contoh yang dianggap albid'ah oleh Syaikh Muhammad Tahir sendiri.

Secara ringkasnya, al-sunnah yang dimaksudkan oleh Syaikh Muhammad Tahir merujuk kepada perkara yang berhubung dengan perkataan, perbuatan dan ketetapan Nabi [s.a.w] (meliputi diam dan tidak menegur perbuatan seseorang di hadapan Nabi [s.a.w] atau sampai khabar kepadanya. Ia melibatkan ketiga-tiga aspek yang dilakukan oleh Nabi [s.a.w], dan sesuatu yang tidak berkaitan dengan Nabi [s.a.w] tidak boleh dikatakan alsunnah.

Al-bid'ah pula menurut beliau pula merujuk kepada sesuatu perbuatan yang tidak wujud pada masa Rasulullah [s.a.w] atau dengan kata-kata lain, yang tidak melibatkan ketiga-tiga aspek tersebut. Bid'ah dibahagi kepada dua, dengan fokus utama adalah kepada bid'ah syar'iyyah, manakala bid'ah lughawiyyah tidak diberikan keutamaan.

Bid'ah syar'iyyah merupakan perkara yang berhubungan erat dengan aspek akidah dan ibadat, dengan sebarang tambahan dalam perkara itu akan mengakibatkan kesesatan (dalalah) sedangkan setiap bid'ah adalah dalalah, dan setiap dalalah akan mendapat balasannya dalam neraka.

Secara perbandingan, daripada keterangan dan perbahasan oleh Syaikh Muhammad Tahir, dapatlah difahami bahwa al-sunnah bukanlah al-bid'ah dan begitulah sebaliknya. Al-Sunnah merupakan bahagian daripada Islam itu sendiri, sedangkan al-bid'ah pula adalah sebaliknya. Perbuatan mengikuti alsunnah menepati kehendak Allah dan Rasul-Nya, manakala mengikuti albid'ah pula menentang kehendak Allah dan Rasul-Nya. Kesannya, al-sunnah adalah ketetapan Allah dan Rasul-Nya manakala al-bid'ah tidak berkaitan dengan Allah dan Rasul-Nya. Justeru, beliau menyeru agar "ikutlah dan taatlah Islam dengan melakukan perintah Allah dan Rasul-Nya dan tidak ingkar dan cuaikan Islam dengan melanggar perintah Allah dan RasulNya." Natijah akhirnya, pelaku al- 
sunnah di syurga sedangkan pelaku albid'ah di neraka.

\section{KESIMPULAN}

Secara keseluruhannya, dapatlah disimpulkan bahwa Syaikh Muhammad Tahir Jalaluddin al-Falaki al-Azhari mempunyai latar belakang Islam yang kuat karena beliau melalui proses pendidikan Islam mengikuti saluran yang lazim diterima oleh kebanyakan tokoh ulama setempat dan serantau. Ide dan pemikiran Syaikh Muhammad Tahir dilihat mewakili aliran al-Salafiyyah [Ultra-Konservatif] dengan rasionalitas. Ia bukanlah aliran yang sepenuhnya bersumberkan alQur'an dan al-Sunnah semata-mata, bahkan disertai dalil dan hujah rasional untuk mendukung maupun menentang pendapat yang ditentang.

Konsep al-sunnah dan al-bid'ah merupakan dua isu besar yang dijadikan fokus utama karena tuntutan zaman dan keadaan pada masa tersebut. Islam pada zaman itu bercampuraduk dengan budaya dan pemikiran Melayu. Ia juga disebabkan bentuk Islam yang dianut bukanlah Islam asal yang dikehendaki Allah dan
Rasul-Nya karena ia berada dalam proses pengislaman atau Islamisasi dan tidak berjalan sepenuhnya seperti yang dikehendaki. Justeru karena itu, kelihatan percanggahan dan pertentangan dengan Islam muncul. Selain itu, Islam yang didakwahkan di alam Melayu dan Malaysia diwarnai pemikiran kemazhaban baik dalam akidah maupun syariah. Mazhabmazhab dalam Islam pula banyak dan pelbagai meliputi mazhab akidah dan syariah juga. Implikasinya, perbedaan dan perselisihan merupakan sesuatu yang tidak dapat dielakkan. Bagaimanapun, dengan faktor 'asabiyyah atau ekstremisme mazhab dan bangsa yang agak kuat telah menenggelamkan sifat dan sikap berpegang kepada Islam tanpa mazhab dan 'asabiyyah. Proses pemisahan antara Islam asli dan Islam budaya menjadi agak sukar dan berat. Oleh karena itu, usaha yang dilakukan oleh Syaikh Muhammad Tahir yang mewakili aliran al-Salafiyyah atau Kaum Muda menghadapi tentangan dan bangkangan yang kuat daripada aliran ASWJ [Sunni] atau Kaum Tua.

\section{DAFTAR PUSTAKA}

Abu Bakar Hamzah, "Sheikh Tahir Jalalu'ddin" dlm. Medium, Akademi Islam, Universiti Malaya, Tahun 1, Bil.1, 1409/1988.

Syaikh Muhammad Tahir Jalaluddin, Kitab Risalah Penebas - Bid'ah-Bid'ah di Kepala Batas. Ibn Qudamah, Kitab al-Mughni, Juz.1.

Al-Razi [m.370], Kitab al-Ahkam al-Qur'an.

Al-Suyuti, Jalal al-Din, al-Durr al-Manthur.

Muhammad bin Idris al-Syafi'i, al-Umm, I.

Ibn Hajr al-Haythami, Fath al-Jawwad.

Kitab Irsyad al-Fuhul.

Ibn Hajar, al-Fatawa al-Hadithihiyyah.

Muslim, Sahih, VI.

Ibn Hajr al-'Asqalani al-Syafi'i, al-Fath, II.

Abu Syamah al-Syafi'i, al-Ba'ith 'ala Ingkar al-Bida'i wa al-Hawadith.

Majd al-Din al-Syirazi al-Syafi'i, Safar al-Sa'adah.

Al-Nawawi, al-Majmu'. 
Hanifiya: Jurnal Studi Agama-Agama

ISSN 2089-8835

Volume 2 Nomor 2 Tahun 2019

Riwayat Ahmad Ibn Hanbal, lihat: Kanz al-Ummal, V.

Ibn Hajr al-Haythami, al-Fatawa al-Hadithiyyah. 